\title{
Estimating MSY and MEY in multi-species and multi-fleet fisheries, consequences and limits: an application to the Bay of Biscay mixed fishery
}

\author{
Jordi Guillen $^{a, *}$, Claire Macher ${ }^{a,}{ }^{*}$, Mathieu Merzéréaud ${ }^{a}$, Michel Bertignac $^{b}$, Spyros Fifas $^{b}$, \\ Olivier Guyader ${ }^{a}$
}

\author{
a IFREMER, UMR AMURE, Unité d'Economie Maritime, BP 70, F-29280 Plouzané Cedex, France \\ ${ }^{b}$ IFREMER, Unité Sciences et Technologies Halieutiques, BP 70, F-29280 Plouzané Cedex, France \\ *: Corresponding authors : Jordi Guillen, email addresses : jordi.guillen.garcia@ifremer.fr ; \\ jordiguillen@hotmail.com ; Claire Macher, email address : claire.macher@ifremer.fr
}

\begin{abstract}
:
Most worldwide fish stocks are overexploited, and so exploited beyond the Maximum Sustainable Yield (MSY) and the Maximum Economic Yield (MEY). Not exploiting fisheries resources at MSY or MEY leads to the loss of production and rents from the fisheries. A large part of the EU fisheries are managed based on single species stock assessments; however, in reality, most species are caught together with other species and by different fleets. In multi-species and multi-fleet fisheries, single species assessments, and consequently MSY and MEY reference points, are often not valid, and so the catch recommendations. In this paper it is investigated the MSY and MEY estimation in multispecies and multi-fleet fisheries in comparison to single species assessments. Analyses are applied to the Bay of Biscay demersal fishery using the IAM bio-economic model. The impact of exploiting at MSY and MEY on the optimal effort allocation between fleets with different exploitation patterns and economic structures is analyzed. When accounting for the multi-species nature of the fishery, MSY landings are $0.4 \%$ to $2.7 \%$ lower than the single species simulations estimates. When accounting for the multi-fleet nature of the fishery, MSY landings are $27.2 \%$ to $30.2 \%$ higher than the single-fleet estimates. When considering the multi-fleet characteristics, MEY landings are $6.6 \%$ higher and profits are $66.5 \%$ higher than in the single-fleet simulation. Optimal effort at MEY is lower than at MSY, but when accounting for multi-fleet the optimal effort decreases for some fleets while increases for gillnetters. The results also provide an estimation of the profits at MEY (or costs of not being at MEY). Profits can be then up to 10.7 times larger than the current profits ( 256 million Euros compared to the current 24 million Euros).
\end{abstract}

\section{Highlights}

MSY and MEY estimates are often not valid in multi-species and multi-fleetfisheries. MSY and MEY estimation is investigated on the Bay of Biscay mixed fishery. The 3 stocks analyzed are overexploited and there is overcapacity in most fleets. When accounting for multi-fleet instead of single fleet, MSY and MEY arehigher. Profits at the MEY could be 10.7 times larger than current ones.

Keywords: MSY ; MEY ; Multi-species ; Multi-fleet ; Fisheries ; Bio-economic model 


\section{Introduction}

Most of the worldwide assessed fish stocks are overexploited, and so not optimally exploited. Worm et al., [1] estimated that $63 \%$ of assessed fish stocks worldwide require rebuilding; while in the EU, $88 \%$ of assessed stocks are being fished beyond the maximum sustainable yield (MSY) ${ }^{1}$, being $30 \%$ of these stocks outside safe biological limits [5]. Estimations of current exploitation levels compared to maximum economic yields $(\mathrm{MEY})^{2}$, and thus, estimation of fleet overcapacities are more scarce [6]. However, a diagnostic of chronic overcapacity has been stated in the green paper [5].

Fish stocks exploited beyond MSY and MEY are thus producing less in biologic and economic terms that what it could be obtained if they were optimally managed. Grainger and Garcia [7] estimated global economic losses from overexploitation to be between 8 and 16 billion USD per year. More recently, the World Bank and FAO [8] estimated that overfishing may cost roughly 50 billion USD a year. Srinivasan et al., [9] estimated global catch losses due to overfishing to be between $7 \%$ and $36 \%$ of the current landings, resulting in a loss between 6.4 and 36 billion USD.

Most countries state that they manage their fisheries to achieve a combination of biological, economic, social, and political objectives [10,11]. However, often there is uncertainty on how these objectives are defined and balanced [6].

The United Nations Convention on the Law of the Sea [12] urges states to set an allowable catch (quotas) designed to maintain or restore stocks to levels supporting MSY. In 2002, the EU, among several countries, agreed to comply with the Plan of Implementation of the Johannesburg World Summit on Sustainable Development [13]. EU Member States thus committed to maintain or restore fish stocks to levels that can

\footnotetext{
${ }^{1}$ MSY can be defined as the maximum annual catch which on average can be taken year after year from a fish stock on a sustainable way -without deteriorating the productivity of the fish stock [2]. So, the MSY should correspond to the catch of an optimally managed fishery (at equilibrium) aiming at maximising production.

On a output managed fishery, the quota should be set equal to the catch at equilibrium; while, on an input managed fishery, it is the total fishing effort that needs to be set to the level necessary to harvest the optimal catch.

${ }^{2}$ MEY can be defined as the sustainable catch that maximizes profits -the difference between total revenues and total costs of fishing [3,4]. So, the MEY should correspond to the catch of an optimally managed fishery (at equilibrium) aiming at maximising profitability.
} 
produce the MSY by 2015 [13]. The 2002 reform of the EU's Common Fisheries Policy [5] also stated that the exploitation of aquatic living resources should ensure economic, environmental and social sustainability ${ }^{3}$.

However, the Common Fisheries Policy has so far failed to assure a sustainable exploitation of the fisheries [5]. The Green Paper on the reform of the EU's Common Fisheries Policy [5] emphasizes the need to address the overcapacity of the fishing fleets and its origins, and to achieve the goal of restoring fisheries to MSY by 2015. One of the main criticisms of the current CFP is that scientific advice has often been poorly or only partially implemented [15,16]. Indeed, Villasante et al., [16] estimated the differences between the fishing quotas and the ICES recommendations to be $19 \%$ after the first CFP reform (1992-2001) and 21\% after the second one (2002-2008).

The US Magnuson-Stevens Fishery Conservation and Management Act [17] also mandates for "sound management to attain optimum yield, which is prescribed as such on the basis of the maximum sustainable yield from the fishery, as reduced by any relevant economic, social, or ecological factor". In addition some international management bodies have MSY as a management objective (i.e. the International Commission for the Conservation of Atlantic Tunas - ICCAT).

In contrast, the Australian Fisheries Management Act 1991 [18] states as an explicit objective maximizing the net economic returns and the economic efficiency (efficient and cost-effective) of fisheries. While the associated Australian Fisheries Harvest Policy [19] reaffirms that the target reference point for the exploitation of a resource should be the maximum economic yield (MEY) or a relevant proxy.

Both Reference Points, the MSY and the MEY, originated from logistic models, and consequently based on models designed for single-species fisheries. The MSY concept has been largely criticized, mainly due to i) its initial static approach, ii) its estimation problems, iii) the possibility that it may not protect against recruitment failure, iv) the impossibility of maximizing sustainable yields for all species simultaneously in

\footnotetext{
${ }^{3}$ By sustainability it is meant that "the exploitation of a stock should be done in such a way that the future exploitation of the stock will not be prejudiced and that it does not have a negative impact on the marine eco-systems" [14].
} 
multispecies fisheries v) it does not ensure that the best economic or social situation will be achieved, and vi) MEY provides a more holistic, and so more ecosystemic, perspective [20-25]. Some of the criticism that MSY has received can also be applied to the MEY concept.

Despite the fact that, in reality, most species are caught together with other species by multiple fleets (multi-species and multi-fleet fisheries), only the multi-species consequences have started to be considered in the analysis $[23,25]$. On this paper we incorporate the presence of multiple fleets in the analysis of the estimation of MSY and MEY reference points on multi-species fisheries. Given the large biological and technical interactions on most worldwide fisheries, an adequate management system based on single-species and single-fleet reference points is unfeasible. Indeed, ICES [26] stated that establishing the biomass at MSY level on a multi-species context has yet to be established, since the optimal fishing effort for one species would be directed to harvest different species, to which different MSYs and MEYs levels of optimal effort might need to be applied. In parallel, on a multi-fleet context the optimal fishing effort needs to be established by fleet, which are harvesting different sets of species and with different exploitation patterns (selectivities) for each of them.

The exploitation of fish stocks by different fleets can lead to changes on the MSY and MEY yield-effort curves depending on the effort allocation among fleets and therefore on global selectivity. This has implications on whether to consider technical and economic efficiency on the definition of MSY and MEY (i.e. by choosing the overall fleet composition), but also political decisions on favoring certain fleets, and consequently rent transfers among fleets and its social impacts.

The Bay of Biscay demersal fishery gives an example of multi-specific context with management objectives of MSY. This mixed fishery is one of the most important fisheries in the Bay of Biscay. More than 550 vessels from France, Spain and Belgium operate on this fishery, targeting mainly nephrops (Norway lobster, Nephrops norvegicus), hake (Merluccius merluccius) and sole (Solea solea) with trawl and gillnets. The French part of the fishery generated 200 million Euros gross return in 2009. Stocks of sole and hake are under long term management plans [27,28] which recently moved to a multi-species management plan to be defined for the Bay of Biscay 
with needs of understanding the interactions between fleets and species and to explore the notion of multi-specific MSY and MEY.

This paper explores the calculation of MSY and MEY in multi-species (nephrops, hake and sole) and multi-fleet (trawlers, trawlers targeting nephrops, gillnetters, gillnetters targeting sole, and other vessels) fisheries, applied to the Bay of Biscay demersal fishery.

\section{Materials and Methods}

\subsection{Bio-economic model}

The bio-economic model IAM (Impact Assessment Model for fisheries management) was developed to assess impacts of management scenarios or scenarios of changes in the economic or/and environmental context of the fishery. The model is developed in $\mathrm{R} / \mathrm{C}++[29,30]$. It is an integrated model coupling the biological dynamics of fish stocks with the economic dynamics to perform impact assessment taking into account the biological impacts and the economic impacts for fleets. The IAM model assesses impacts in the short, medium and long terms, transition phases, and impacts distributions between different fleets. The model is multi-species, multi-fleets and multi-métiers. It age structured, spatially aggregated and has an annual time step. The model is structured on a modular basis to allow flexibility in the development. The bio economic model calculates at each time step fishing mortality, spawning biomass, biomass, total catches, catches by fleet, fleet and individual economic performances, the total number of vessels by fleet, employment and crew salaries. The model can assess the impacts of various management scenarios: fishing gear selectivity improvement, decrease in time fishing per vessel, decrease in the number of vessels, quota constraints. The model was used to explore bio-economic impacts of several pathways to MSY for decision support within STECF working groups on management plan for sole in the Bay of Biscay [31]. Other applications of the model deal with bio-economic impacts of selectivity improvements [32]. Main equations of the model are described in more detail in Macher et al. [33].

On the IAM model, fishing mortality $(F)$ is proportional to fishing effort $(E)$ : 


$$
\left.F_{s, i, f}=E_{s, i, f} \times q_{s, i, f} \quad \text { (equation } 1\right)
$$

where $q$ is the catchability by fleet, species and age-class.

Catches in number per species, per fleet and per age group $\left(C n_{s, i, f}\right)$, are related to fishing mortality, by the following equation:

$$
C n_{s, i, f}=F_{s, i, f} \times N_{s, i} \times \frac{\left(1-e^{-Z_{s, i, f}}\right)}{Z_{s, i ; f}}
$$

where $N$ the total number of individuals and $Z$ the total mortality.

Landings in number are equal to catches minus discards in number. Discards in number $(D n)$, by age-class are estimated in the model by:

$$
D n_{s, i, f}=C n_{s, i, f} \times d_{s, i, f} \quad(\text { equation } 3)
$$

where $d$ is the percentage discarded in number by age-class. In this study we assume a constant discarding behavior, the percentage of discards by species, fleet, and age is considered constant over time.

The revenues (Gross value of landings) per fleet are obtained by adding the revenues from the modeled species $(s)$ and the ones from other species not modeled (oths):

$$
G V L_{f}=\sum_{s}\left(P_{s, f} \times L_{s, f}\right)+G V \text { Loth }_{f} \quad \text { (equation 4) }
$$

Where $P$ is the price by species and fleet, $L$ is the weight of landings by species and fleet, and $G V L$ is the gross value of landings.

The revenues from other species rather than the three modeled species (nephrops, hake and sole) have been estimated following two different approaches.

- Assuming that the other species revenues remain constant.

- Assuming that the variation in the other species revenues is proportional to the variation of the sum of nephrops, hake and sole revenues.

Economic performance indicators are calculated following the methodology established on the Annual Economic Report [34]. Therefore, the Gross Value Added by fleet is estimated: 


$$
G V A_{f}=G V L a v_{f}-\text { fuec }_{f}-o v c_{f}-\text { rep }_{f}-\text { Fixc }_{f} \quad \text { (equation 5) }
$$

Where fuec is fuel costs, ovc is other variable costs, rep is reparations and maintenance and Fixc is fix costs.

Profitability is estimated by the Gross Cash Flow $(G C F)^{4}$.

$$
G C F_{f}=G V L a v_{f}-\text { fuec }_{f}-o v c_{f}-r e p_{f}-F_{i x c}-c c w_{f} \quad \text { (equation 6) }
$$

Where $c c w$ is the crew costs 5 .

Effort adjustments (increases or decreases) by fleet are done through the number of vessels that participate in the fishery. Fishing effort (fishing days) by vessel and season is assumed to be constant for the analysis. Thus, variations of effort simulated in this paper correspond to capacity adjustments. Costs (variable costs and fixed costs) by fleet are assumed here to be proportional to the number of vessels in the fleet (i.e. to the effort).

Simulations on catch and landing evolutions for the fishery, and the different species in particular, and the economic performance of the different fleets were performed with the IAM model according to a range of effort multipliers. The MSY values (maximum landings), MEY values (maximum profits), the corresponding effort and biomass at equilibrium were obtained by optimization with the IAM model.

The model operates under several assumptions for this particular Bay of Biscay case study:

- constant price by commercial grades

- constant catchability and strategies of effort allocation by métier

- Hockey stick stock-recruitment relationships for sole, hake and nephrops ${ }^{6}$.

\footnotetext{
${ }_{5}^{4}$ Capital data are not included in the profits calculation because of the lack of quality of the data.

${ }^{5}$ Crew wages are considered fixed. This assumption has been taken to avoid unrealistic increases in wages on the optimal exploitation levels.

${ }^{6}$ Hockey stick stock-recruitment relationships have been chosen because they offer a shape closer to the production functions usually used in more theoretically economic models and more realistic when considering impact of high effort levels on recruitment. It should be noted that for nephrops the parameters have been arbitrarily chosen from the stock assessment data since there is no perception of inflexion points on the data. However, the optimal reference points are independent on the stockrecruitment relationships.
} 


\subsection{Data}

The bio-economic model was parameterized with the outputs from the stock assessments performed by the ICES for year 2009 (i.e. fishing mortality, stock numbers at age, mean weight at age) for the stocks of nephrops in the bay of Biscay and Northern hake [35] and performed during the benchmark on flat fish for the stock of sole in the bay of Biscay [36]. Hockey-stick stock-recruitment relationships were adjusted based on the 1990-2006 data for hake, on 1987-2009 data for nephrops and on 1993-2006 data for sole.

Fleets data on fleets structure, productions and costs were parameterized from indicator calculations on 2009 data from the Ifremer's Fisheries Information System that gathers data from Ifremer and from the French administration collected notably within the DCF regulation framework [37-40].

Vessels catching nephrops, hake or sole in the Bay of Biscay were classified into 5 different fleet segments according to their strategies: trawlers targeting nephrops all year long and depending on nephrops for more than $40 \%$ of their gross revenue, mixed trawlers, gillnetters targeting sole and for which sole represents more than $30 \%$ of the gross revenue or mixed gillnetters. The fleet "others" includes the vessels that could not be classified into the previous fleets but contributes to the fishing mortality of these species (either in the Bay of Biscay or for the Northern hake stock) and for which all the data were not available (i.e. Spanish fleet targeting hake for which economic data were not available). This fleet "others" could therefore not be fully modeled but only for its impacts on stocks.

Figure 1 
Table 1 shows the number of vessels, fishing mortality per species $(F)$, quantities $(\mathrm{Q})$, discards (D), landings (L) and value of landings (V) for each species and in totals, total costs and economic performance detailed by fleet.

Table 1

In 2009, the Bay of Biscay demersal mixed fishery produced ${ }^{7}$ a turnover (gross landings value) of more than 200 million Euros, a Gross Value Added of more than 100 million Euros and profits of almost 24 million Euros.

\section{Results}

\section{Single species MSY estimation}

In the Bay of Biscay demersal mixed fishery, the main three species targeted are nephrops, hake and sole. For each of the three species, the optimal fishing mortality and effort ( $\mathrm{E}_{\mathrm{MSY}}$ ) corresponding to the maximum sustainable yield is estimated (Figures 2a to $2 \mathrm{c})$.

In MSY, the choice of yield as landings or catches is a matter of policy [41]. If yield is considered to be the quantity that is removed from the stock, then it should refer to maximizing catch. In the current study, yields will refer to landings. If yield is considered to be the utilized part from the removed stock, and so the amount contributing to economic or social activity, then yield should refer to landings. Discards for nephrops and hake occur mainly because of minimum landing size regulations; while there are no significant discards of sole due to a better selectivity of the fleets.

For this MSY estimation we initially assume that increases (decreases) on the global fishing mortality will lead to proportional increases (decreases) on the fishing mortality for each of the fleets, and so on their fishing effort. Thus, the global exploitation pattern (selectivity) of the fishery remains constant.

(Figures $2 a-2 c$ to be placed here)

\footnotetext{
${ }^{7}$ For the fleets were economic data is available, so excluding the "other" fleet.
} 
As it can be seen from previous figures $(2 \mathrm{a}-2 \mathrm{c})$, all 3 fish stocks are overexploited, because current exploitation levels (effort multipliers equal to 1) are higher than the optimal effort ( $\left.\mathrm{E}_{\mathrm{MSY}}\right)$. More landings could be obtained on a sustainable way if an effort lower than current effort was applied.

In fact, with single species simulations, the maximum sustainable landings that can be obtained are 4,631 tons of nephrops landings with a fishing effort 34\% lower than current effort, 67,728 tons of hake with an effort $54 \%$ lower and 4,860 tons of sole with an effort $23 \%$ lower, as can be seen from table 2. While landings for nephrops, hake and sole in the initial period (on 2009) accounted for 26\% less, 4,099, 52,917 and 4,210 tons respectively (from table 1). This implies that all stocks will benefit from effort reductions.

\section{Effect of technical interactions in multi-species fisheries}

Optimal fishing effort levels for nephrops, hake and sole are respectively $34 \%, 54 \%$ and $23 \%$ lower than the current effort level. However, since these species are in technical interactions through fleets, the same effort level should be applied to all of them.

We then estimate the MSY on the aggregate catches by summing up the sustainable production curves for all 3 species [42-44] (Figure 3).

(Figure 3 to be placed here)

Therefore, the effort level that maximizes together the landings of nephrops, hake and sole is a $52 \%$ lower than current effort, as can be seen on figure 3 . The optimal fishing effort that maximizes landings is close to the optimal effort that maximizes hake catches due to the large landings that can be obtained from this stock, in comparison to the nephrops and sole ones. Total landings obtained by maximizing nephrops, hake and sole individually (single-species simulations) are $2.6 \%, 0.0 \%$ and $3.3 \%$ higher than the landings obtained at the effort level that maximizes the sum of all 3 species $(4,631$ tons, 67,728 tons and 4,860 tons compared to 4,514 tons, 67,701 tons and 4,706 tons, as reported in table 2). 
Our analysis shows that the optimal fishing efforts for each of the species on singlespecies simulations are between $46 \%$ and $77 \%$ of current effort level (figure 3 ). While the optimal total effort is $48 \%$ of current effort level. This effort level is significantly lower than the optimal efforts for nephrops and sole, however, their total landings are not reduced so significantly. At the optimal effort level on the multi-species simulation the biomass at sea of nephrops and sole is larger than at the single-species simulations, but for hake the biomass is slightly lower (less than 3\%).

From a precautionary point of view, regarding stocks preservation, the level of exploitation should be the one that takes into consideration the most vulnerable species of the fishery. That would consist to set the total effort level to $46 \%$ of current effort, which is the optimal effort for hake, the most restrictive one (in this case, it is not relatively different from the total optimal effort). It should be noted that the more a fish stock is overexploited there are more chances that it can suffer a collapse since stock fluctuations become wider, and the time span needed to re-attain equilibrium increases [45].

\section{Optimal effort allocation by fleet: including dynamics in the multi-fleet concept}

Changes in selectivity can alter the MSY curve, and consequently the optimal yield and effort [2,32,46-48]. Similarly, it is possible to increase the MSY yield by changing the exploitation pattern (global selectivity) on a multi-fleet fishery (i.e. by reducing effort by fleet differently according to their exploitation pattern/selectivity). Therefore, maximization of landings will be obtained by choosing the optimal effort allocation by fleet, and so that means by choosing exploitation patterns and effort that maximize productions. According to the fishery status, effort of low selective fleets will be thus more reduced than effort of higher selective fleets to maximize landings.

Table 3 reports the optimal distribution of effort among fleets that maximizes the landings for each of the three simulated species and for the sum of them. So, the results account for the multi-fleet characteristics of the fishery.

(Table 3 to be placed here) 
From the effort values on table 3, we construct the effort-field curves (figures 4a-4d) for the optimal fleet combination for each of the three species and the sum of them, taking as 1 the optimal effort level reported in the table.

\section{(Figure 4a-4d to be placed here)}

From single species simulations (figures 4a-4c), the maximum landings of nephrops (MSY level) are 4,631 tons, a $0.0 \%$ higher than when the multi-fleet characteristics of the fishery (so that effort allocation among fleets was proportional) were not considered. The maximum landings of hake could be reached if only gillnetters were harvesting it, with 90,960 tons, a 34\% higher yield. While for sole the maximum landings are 4,992 tons, 3\% higher than previously, when only gillnetters are fishing it. The resulting biomass at sea is almost the same for nephrops, lower for hake and larger for sole, when compared to the single-species simulation with fix allocation of effort by fleet (first part of table 2).

When considering the multi-species and multi-fleet character of the fishery (figure $4 \mathrm{~d}$ and second part of table 2), the maximum landings of nephrops, hake and sole are $3,648,89,232$ and 4,973 tons, respectively (a 27\%, 2\% and $0.4 \%$ reduction of single species simulation yields with optimal allocation of fishing effort). The maximum landings are obtained by increasing the effort for mixed gillnetters that have a better selectivity for hake and low (or null) impacts on the nephrops and sole stocks, reducing effort for trawlers targeting nephrops and gillnetters targeting sole that have high contributions to fishing mortality of nephrops and sole and by assuming that mixed trawlers and "other" fleet do not participate in the fishery. The resulting biomass at sea is much larger for nephrops, even lower for hake and larger for sole, when compared to the single-species simulation with fix allocation of effort by fleet.

\section{MEY}

The MSY concept only takes into consideration the biological dynamics. It is moreover a single species notion. From an economic perspective, the objective is not to provide the maximum amount of fish that can be harvested from a stock on a sustainable way as MSY do but to provide the maximum of rent from catches. MEY objective is to 
optimize the profits that can be obtained from the fishery. From this point of view MEY is a multispecies notion that considers economic dynamics of the fisheries activity and includes fishing costs in addition to the biological dynamics $[6,49,50]$.

\section{MEY estimation considering proportional effort allocation by fleet}

The MEY is estimated both assuming that other species landings remain constant and consequently their revenues; and that the other species landings and revenues are proportional to the total nephrops, hake and sole landings ${ }^{8}$. Results are presented on table 4 and represented on figures $5 \mathrm{a}$ and $5 \mathrm{~b}$.

\section{(Table 4 to be placed here)}

The MEY value is found to be positioned on the left and below the MSY as expected by the fishery economics theory. Therefore, the fishing effort and the landings are lower at the MEY level compared to the MSY level [49-51]. Optimal effort to maximize profits from the fishery would be between 0.22 (assuming other species revenues constant) and 0.39 (assuming other species revenues proportional to the three species modeled) of current effort, an effort lower than the 0.48 that was estimated when it is aimed to maximize landings.

Nephrops, hake and sole represent $48 \%$ or $70 \%$ of total revenues from the fleets analyzed, depending whether other species are considered constant or proportional. Profits are higher when assuming other species constant due to the lower costs and the significance from the other species constant revenues.

When assuming that other species are constant, with an effort of 0.22 of the current effort, then profits would be 154 million Euros (value of landings would be 195 million Euros and costs 41 million Euros). The profitability is 6.4 times higher than in the current situation (Effort equal to 1), where profits are almost 24 million Euros (table 1). While when assuming that other species are proportional to the species modeled, with an effort of 0.39 of the current effort, then profits would be 85 million Euros (value of landings would be 157 million Euros and costs 72 million Euros). The profitability is

\footnotetext{
${ }^{8}$ If assuming other species revenues proportional to effort, the effort for some fleets would increase on an unrealistic way.
} 
3.5 times higher than in the current situation. Difference of profits at MEY and current profit gives an estimation of the costs of overcapacity and overexploitation.

\section{(Figures $5 a-5 b$ to be placed here)}

If current effort increases by $21 \%$, then we would be on the open access point, where profits are dissipated, since the fishing cost equal the revenues.

\section{MEY estimation considering the optimal effort allocation by fleet (multi-fleet nature)}

The assumption of a constant proportion of the fleets in the total fishing fleet is relaxed and we assume that effort can be allocated independently by fleet. This results in determining the effort allocation by fleet that maximizes profit.

\section{(Table 5 to be placed here)}

When considering the multi-species and multi-fleet character of the fishery (and according to assumptions on species dynamics included in the model), the optimal allocation of effort by fleet that maximizes profits is obtained, as can be seen on table 5 (see also figures 6a-6b), when:

- Mixed trawlers and "other" fleet do not participate in the fishery

- mixed gillnetters increase their effort,

- trawlers targeting nephrops reduce their effort,

- gillnetters targeting sole reduce their effort with the assumption of constant other species,

- gillnetters targeting sole exit from the fishery with the assumption that other species are proportional to effort.

It should be noted that nephrops, hake and sole represent $72 \%$ (assuming other species revenues constant) and 6\% (assuming other species revenues proportional) of total revenues from the fleets analyzed. Profits are unrealistically higher when assuming other species proportional, because of the assumption itself. This optimal is reached by increasing effort from gillnetters to more than 62 times current effort (i.e. if there are 
currently 86 gillnetters, these result would imply the need to have 5,358 gillnetters on the fishery). This result is unrealistic and would not be acceptable to industry or managers. In addition, the biomass at sea of hake and sole are very low, so from a precautionary approach this possibility also needs to be excluded.

The results obtained assuming the other species constant are more realistic and similar to the MSY optimal. The maximum landings of nephrops, hake and sole are 3,756, 62,416 and 4,227 tons, respectively (a 3\% increase for nephrops, but a 30\% and 15\% decrease for hake and sole from the MSY estimates considering the multi-species and multi-fleets characteristics of the fishery). The resulting biomass at sea is much larger for hake and sole than at the MSY level, while for nephrops is lower, but still larger than any of the MSY single-species simulations.

When comparing these results to the MEY calculations considering that different efforts could not be allocated between the fleets (see table 4), the landings for all three modeled species are higher when effort can be optimally allocated between species and profits are $67 \%$ higher.

\section{(Figures 6a-6b to be placed here)}

In this case, the economic equilibrium is also more stable since the open access point would be situated 3.7 times the optimal effort.

Therefore, the analyses for the demersal fishery in the Bay of Biscay show that when accounting for the multi-species nature, MSY landings are $0.4 \%$ lower than the single species simulations estimates (see table 2). This small difference happens because of the high importance of hake landings on the results. While when accounting for the multifleet nature of the fishery, MSY landings are $2.7 \%$ lower than the single species simulations estimates table 3). However, when considering the multi-fleet characteristics (effort can be allocated by fleet) the MSY landings are $30.2 \%$ (for singlespecies) and $27.2 \%$ (for multi-species) higher than for single-fleet simulation (effort proportional by fleet). While when considering the multi-fleet characteristics, the MEY landings are $6.6 \%$ and $7.9 \%$ higher than for single-fleet simulation (see table 4 and 5). At the MEY level, profits are 6.4 times and 10.7 times larger than the current profits, 
when it is accounted for the single-fleet and multi-fleet characteristics of the fishery (154 million Euros and 256 million Euros compared to the current 24 million Euros profits). Therefore the costs for the Bay of Biscay demersal fishery not to be optimally managed are estimated here to be 232 million Euros per year according to assumptions and species and fleets considered in the analysis.

\section{Discussion}

All simulations where effort allocation by fleet is proportional (see tables 2 and 4 ) lead to effort reductions, which would lead to larger biomass at sea per species. Therefore, the fishery studied show clear signs of overexploitation for all three stocks assessed and overcapacity on most of their fleets. From the single-species simulations (see table 2), hake appears to be the most overexploited species and so, the one that requires further effort reductions (54\% effort reduction needed for hake, compared to $34 \%$ reduction for nephrops and $23 \%$ reduction for sole). This situation is in part due to hake being fished with trawlers that have a low selectivity. This is reflected when effort allocation is allowed to vary by fleet (see table 3), because the optimal gear to harvest hake is gillnetters that have better selectivity.

A reduction between $61 \%$ and $78 \%$ of the vessels (effort) in the modeled fleets of the fishery (depending whether other species revenues is assumed proportional or constant) would indeed maximize the profit when reducing proportionally all the fleets (see table 4). By allocating effort by fleet according to their exploitation pattern (selectivity), only a reduction by $31 \%$ is needed (see table 5 ). This highlights the complementarity existing between reducing effort or increasing selectivity. This overall reduction would not affect all fleets identically. The optimal effort allocation by fleet depends on their contribution to total fishing mortality and selectivity pattern. Trawlers mix and the "other" fleet would not participate in the fishery anymore, trawlers targeting nephrops and gillnetters targeting sole would reduce their effort, and gillnetters mix would increase their effort to maximize profits according to assumptions on species dynamics included in the approach.

In the optimization considering the effort by fleet proportional, the effort that corresponds to the economic optimum MEY (see table 4) is lower than that of the biological MSY and the size of the stock is larger (see table 2). Therefore, the adoption 
of the MEY as a target would potentially reduce the risk of overexploitation of resources in this particular fishery. However, when considering that effort can be allocated by fleet, the single-species economic approach (MEY) follows different and much more complex guidelines. Compared to the MSY level, in multi-species fisheries the level of effort corresponding to the MEY can no longer be considered as a more prudential value. Indeed, since it depends on the ratios between the prices of the different species, it is likely to be positioned either on the left or on the right of the $\mathrm{E}_{\mathrm{MSY}}$ value. The latter case is expected to occur when consumers' choices determine a higher price of the most productive species.

Indeed, from a multi-fleet point of view, this is not so straightforward, since it is possible that when comparing two simulations it is optimal that effort from a fleet decreases while from another increases. In fact, for MEY (see table 5) it is recommended an effort of 0.36 trawlers targeting nephrops, 0 for trawlers mix, 0.29 for gillnetters targeting sole, 2.97 for gillnetters mix and 0 for others. While optimal effort at MSY (see table 3) is $0.34,0,0.69,11.95$ and 0 , respectively. So the MEY simulation estimates effort level for trawlers targeting nephrops higher than the one estimated by the MSY simulation, but effort for gillnetters targeting sole and gillnetters mix is lower. In that case, it is necessary to look at the biomass at sea for each of the species and the biomass of it is lower at the nephrops MEY simulation, while the hake and sole ones are higher. Therefore, for multi-fleet fisheries, MEY is not necessarily more precautionary than MSY, since although global effort is often lower, but the effort targeting a particular species can be higher. Thus, it arises the need to set limit reference points in multi-species fisheries, according to the knowledge of the fish stocks, so that MSY and MEY estimations can be directly applied on fisheries management.

The level of effort associated with MEY is however likely to fluctuate as a consequence of the changes in the variables of the reference economic framework, such as the cost of fishing activities (mainly fuel costs) and the price of landings. When the price is a function of the catch quantity and, therefore, of the offer, low levels of catch may also correspond to higher profits. In these cases, the economic optimum will be positioned at lower levels of effort in the long-term equilibrium curve. When fuel price vary, the costefficiency of the different fleets also vary. Therefore, fuel prices increases can lead to 
effort reductions on the most fuel depending fleets, and so effort increases in the less fuel depending fleets, changing the overall exploitation pattern.

It should be considered that similar studies on other fisheries can produce very different estimations and consequently MSY and MEY recommendations. It should be also noted that for this fishery full data is available for the three main species (nephrops, hake and sole), so other species are modeled following two different assumptions. Similarly, biological data of the catches is available for all fleets, but economic data is available for four of the five fleets modeled, this prevented the "other" fleet to be part of the economic optimal effort allocations. This is a shortcoming, especially because of the importance of this "other" fleet on the hake catches. Also, opportunity costs of labor and capital were not included on the MEY calculation, and so it is based only on the profit estimated by the gross operating surplus which is an approximation of the owner surplus. MSY and MEY estimations are dependent on the stock-recruitment relationship that is often poorly understood [52-55]. The analyzes provided on this study are at the optimal situation in equilibrium. This enables to provide results by comparing current situation to optimal one (MSY and MEY), a step forward would be to analyze scenarios to reach these points by taking into account transition periods, discount rate and preferences for present. Finally, we are basing the economic optimization solely on the profits that can be directly extracted from the fishery, and not on the rents that can be further obtained through processing, distribution and marketing [56-58].

\section{Conclusions}

Estimations of MSY and MEY performed in this paper show that increases of the overall landings and economic performances can be obtained by fishing effort reductions and global selectivity improvements in the Bay of Biscay demersal fishery. In this paper we have also shown the importance of accounting for the multi-fleet nature of the fisheries, and so the capacity to allocate fishing effort between fleets to obtain better yields taking into account joint production processes, various métiers and reallocation of effort (both in production and economic terms).

In output managed fisheries, quota recommendations consistent with MSY and MEY estimations should also help preventing discards, illegal landings and loss of fishing opportunities created by fleets reaching single species quotas at different rates as 
highlighted by Vinther et al., [59] and Pascoe et al., [60]. Estimating profitability changes when fishing at MEY and in the current situation of overcapacity and overexploitation offers an estimation of the costs of not fishing at MSY and MEY, or of the "degradation costs" as called within the Marine Strategy Framework Directive [61].

\section{Acknowledgements}

This work has been carried out with the support of the French Research Agency, ANR, (Agence National pour la Recherche) through the research program entitled Adhoc; and with support of the French Directorate of Sea Fisheries and Aquaculture of the French Ministry of Ecology, sustainable development and ecology through the partnership on the bioeconomic working group project.

\section{References}

[1] Worm B, Hilborn R, Baum JK, Branch TA, Collie JS, Costello C, Fogarty MJ, Fulton EA, Hutchings JA, Jennings S, Jensen OP, Lotze HK, Mace PM, McClanahan TR, Minto C, Palumbi SR, Parma AM, Ricard D, Rosenberg AA, Watson R, Zeller D. Rebuilding global fisheries. Science 2009; 325: 578-585.

[2] Beverton RJH, Holt SJ. On the dynamics of exploited fish populations. United Kingdom Ministry of Agriculture and Fisheries, Fishery Investigations, Series II, Volume XIX. London. 1957.

[3] Huntsman AG. Research on use and increase of fish stocks. Proceedings of the United Nations Scientific Conference on the Conservation and Utilization of Resources. 1949.

[4] Gordon HS. The economic theory of a common property resource: the fishery. J. Polit. Econ. 1954; 62: 124-142.

[5] Commission of the European Communities (EC). Green Paper on the Reform of the Common Fisheries Policy. Brussels, 22.4.2009, COM(2009) 163 final. 2009.

[6] Dichmont CM, Pascoe S, Kompas T, Punt A, Deng R. 2010. On implementing maximum economic yield in commercial fisheries. In: Proceedings of the National Academy of Sciences 2010; 107: 16-21.

[7] Grainger RJ, Garcia SM. Chronicles of marine fishery landings (1950-1994): Trend analysis and fisheries potential, FAO Fisheries Technical Paper $N^{\circ} 359$, Rome: Food and Agriculture Organization of the United Nations. 1996. 
[8] World Bank and FAO. The Sunken billions: the economic justification for fisheries reform. Washington D.C. 130 p. 2009.

[9] Srinivasan UT, Cheung WWL, Watson R, Sumaila UR. Food security implications of global marine catch losses due to overfishing. Journal of Bioeconomics 2010; 12: 183-200.

[10] Mardle S, Pascoe S, Boncoeur J, Le Gallic B, Garcia-Hoyo JJ, Herrero I, JimenezToribio R, Cortes C, Padilla N, Nielsen JR, Mathiesen C. Objectives of fisheries management: Case studies from the UK, France, Spain and Denmark. Marine Policy 2002; 26: 415-428.

[11] Hilborn R. Defining success in fisheries and conflicts in objectives. Marine Policy 2007; 31: 153-158.

[12] United Nations. 1982. United Nations Convention on the Law of the Sea (UNCLOS).

[13] United Nations. Report of the World Summit on Sustainable Development, Johannesburg, South Africa. 2002.

[14] Commission of the European Communities (EC). Council Regulation (EC) No $2371 / 2002$ of 20 December 2002 on the conservation and sustainable exploitation of fisheries resources under the common fisheries policy. Official Journal of the European Communities L 2002; 358: 59-80.

[15] Daw T, Gray T. Fisheries science and sustainability in international policy: a study of failure in the European Union's Common Fisheries Policy. Marine Policy 2005; 29: 189-197.

[16] Villasante S, García-Negro M.-C, González-Laxe F, Rodríguez Rodríguez G. Overfishing and the Common Fisheries Policy: (un)successful results from TAC regulation? Fish and Fisheries 2011; 12: 34-50.

[17] US Department of Commerce - NOAA - NMFS. 2007. National Oceanic and Atmospheric Administration, as amended through January 12, 2007. http://www.nmfs.noaa.gov/msa2005/docs/MSA_amended_msa\%20_20070112_FINAL. pdf

[18] Fisheries Management Act 1991. Act No. 162 of 1991 as amended, taking into account amendments up to Act No. 104 of 2007. http://www.comlaw.gov.au/Details/C2004C00260

[19] DAFF. Australian Fisheries Harvest Policy: Policy and Guidelines. Department of Agriculture, Fisheries and Forestry. Canberra. 2007. 
[20] Larkin PA. An epitaph for the concept of maximum sustained yield. Transactions of the American Fisheries Society 1977; 106: 1-11.

[21] Gislason H. Single and multispecies reference points for Baltic fish stocks. ICES Journal of Marine Science 1999; 56: 571-583.

[22] Punt AE, Smith ADM. The gospel of maximum sustainable yield in fisheries management: birth, crucifixion and reincarnation. In: Reynolds JD, Mace GM, Redford KH, Robinson JG, editors. Conservation of exploited species. Cambridge, UK: Cambridge University Press; 2001; 41-66.

[23] Mace PM. A new role for MSY in single-species and ecosystem approaches to fisheries stock assessment and management. Fish and Fisheries 2001; 2: 2-32.

[24] Walters CJ, Christensen V, Martell SJ, Kitchell JF. Possible ecosystem impacts of applying MSY policies from single-species assessment. ICES J. Mar. Sci. 2005; 62: 558-568.

[25] Matsuda H, Abrams P. Maximum yields from multispecies fisheries systems: rules for systems with multiple trophic levels. Ecological Application 2006; 16: 225-37.

[26] ICES. Report of the Working Group on Multispecies Assessment Methods (WGSAM), 6-10 October 2008, Copenhagen, Denmark, ICES CM 2008/RMC:06. 2008 .

[27] Commission of the European Communities (EC). Council regulation (EC) No 388/2006 of 23 February 2006 establishing a multiannual plan for the sustainable exploitation of the stock of sole in the Bay of Biscay.

[28] Commission of the European Communities (EC). Council regulation (EC) No $811 / 2004$ of 21.4 .2004 establishing measures for the recovery of the Northern hake stock.

[29] Sarkar D. 2008. Lattice: Multivariate Data Visualization with R. Springer, New York. ISBN 978-0-387-75968-5.

[30] R Development Core Team. 2011. R: A language and environment for statistical computing. R Foundation for Statistical Computing, Vienna, Austria. ISBN 3-90005107-0. http://www.R-project.org/

[31] STECF. Impact Assessment of Bay of Biscay sole (STECF-11-01). Simmonds J, Biais G, Bertignac M, Macher C, Merzereaud M, Scott R, Vanhee W. Ed. Copenhaguen, Denmark. 41 pp. 2011.

[32] Raveau A, Macher C, Méhault S, Merzéréaud M, Le Grand C, Guyader O, Bertignac M, Fifas S, Guillen J. 2012. A bio-economic analysis of experimental 
selective devices to improve bottom trawlers selectivity in the Nephrops-hake fishery of the Bay of Biscay. Aquatic Living Resources, in press.

[33] Macher C, Guyader O, Talidec C, Bertignac M. A Cost-benefit Analysis of Improving Trawl Selectivity in the Case of Discards: The Nephrops norvegicus Fishery in the Bay of Biscay. Fisheries Research 2008; 92: 76-89.

[34] STECF (Scientific, Technical and Economic Committee for Fisheries). The 2011 Annual Economic Report on the EU fishing fleet. Publications Office of the European Union. Luxembourg. ISBN 978-92-79-22326-6. ISSN 1018-5593. 233 pp. 2011.

[35] ICES. Report of the Working Group on the Assessment of Southern Shelf Stocks of Hake, Monk and Megrim (WGHMM), 5 - 11 May 2010, Bilbao, Spain. ICES CM 2010/ACOM:11. 599 pp. 2010.

[36] ICES. Report of the Benchmark Workshop on Flatfish (WKFLAT), 1-8 February 2011, Copenhagen, Denmark. ICES CM 2011/ACOM:39. 257 pp. 2011.

[37] Berthou P, Guyader O, Leblond E, Demanèche S, Daurès F, Merrien C, Lespagnol P. From fleet census to sampling schemes: an original collection of data on fishing activity for the assessment of the French fisheries. ICES CM 2008/ K: 12, Halifax.

[38] Daurès F, Van Iseghem S, Demanèche S, Leblond E, Brigaudeau C, Guyader O, Berthou P. Re-assessing the French small-scale coastal fisheries: from fleet activity to economic performance. ICES CM 2008 / K:10, Halifax.

[39] Leblond E, Daurès F, Berthou P, Merrien C, Pitel M, Macher C, Le Grand C, Demanèche S, Jezequel M, Bodéré E, Le Blond S. Synthèse des flottilles de pêche 2009 - Flotte Mer du Nord - Manche - Atlantique et Flotte Méditerranée. Ifremer, SIH Synthèses, 2011. pp. 294.

[40] Van Iseghem S, Quillerou E, Brigaudeau C, Macher C, Guyader O, Daures F. Ensuring representative economic data: survey data-collection methods in France for implementing the Common Fisheries Policy. Ices Journal of Marine Science 2011; 68: 1792-1799.

[41] ICES. Report of the Workshop on Implementing the ICES Fmsy framework, 22-26 March 2010, Copenhagen, Denmark. ICES CM 2010/ACOM:54. 83 pp. 2010.

[42] Accadia P, Placenti V, Spagnolo M. Reference points: a bio-economic model based approach. In: Lembo G. (ed.). Selected papers presented at the workshop on biological reference points. Rome, 20-21 April 2004. Studies and Reviews. General Fisheries Commission for the Mediterranean. No 83. Rome, FAO. 80pp. 2006. 
[43] Punt AE, Smith ADM. The gospel of maximum sustainable yield in fisheries management: birth, crucifixion and reincarnation. In: Conservation of exploited species (Reynolds JD, Mace GM, Redford KR, Robinson JR, eds.). Cambridge University Press. UK. 2001.

[44] Larkin PA. An epitaph for the concept of maximum sustained yield. Transactions of the American fisheries society 1977; 106: 1-11.

[45] Beddington JR, May RH. Harvesting natural populations in a randomly fluctuating environment. Science 1977; 197: 463-465.

[46] Scott R, Sampson D. The sensitivity of long-term yield targets to changes in fishery age-selectivity. Marine Policy 2010; 35: 79-84.

[47] Macher C, Boncoeur J. Optimal Selectivity and Effort Cost A Simple Bioeconomic Model with an Application to the Bay of Biscay Nephrops Fishery. Marine Resource Economics 2010; 25(2): 213-232.

[48] Cardinale M, Hjelm J. Size matters: Short term loss and long term gain in a sizeselective fishery. Marine Policy 2012; 36: 903-906.

[49] Kompas T. Fisheries management: economic efficiency and the concept of 'Maximum Economic Yield'. Australian Commodities 2005; 12: 152-160.

[50] Grafton RQ, Kompas T, Hilborn RW. Economics of overexploitation revisited. Science 2007; 318:1601.

[51] Clark CW. Mathematical Bioeconomics: The Optimal Management of Renewable Resources. Wiley, New York. 1990.

[52] Rostchild BJ, Fogarty MJ. Spawning stock biomass: a source of error in recruitment/ stock relationship and management advice. ICES Journal of Marine Science 1989; 45: 131-135.

[53] Hilborn R, Walters CJ. Quantitative Fisheries Stock Assessment: Choice, Dynamics and Uncertainty. New York, NY: Chapman and Hall. 1992.

[54] Myers RA, Mertz G. Reducing uncertainty in the biological basis of fisheries management by meta-analysis of data from many populations: a synthesis. Fisheries Research 1998; 37: 51-60.

[55] Needle CL. Recruitment models: diagnosis and prognosis. Reviews in Fish Biology and Fisheries 2002; 11: 95-111.

[56] Christensen, V. MEY = MSY. Fish and Fisheries 2010; 11(1): 105-110.

[57] Sumaila UR, Hannesson R. Maximum economic yield in crisis? Fish and Fisheries, 2010, 11: 461-465. 
[58] Norman-Lopez A, Pascoe S. Net economics of achieving maximum economic yield in fisheries. Marine Policy 2011; 35: 489-495.

[59] Vinther M, Reeves S, Patterson K. From single-species advice to mixed-species management: taking the next step. ICES J. Mar. Sci. 2004; 61: 1398-1409.

[60] Pascoe S, Koundouri P, Bjorndal T. Estimating targeting ability in multi-species fisheries: A primal multi-output distance function approach RID D-9710-2011. Land Economics 2007; 83: 382-397.

[61] European Commission. Directive 2008/56/EC of the European Parliament and of the Council of 17 June 2008 establishing a framework for community action in the field of marine environmental policy (Marine Strategy Framework Directive). Official Journal of the European Union. Luxemburg. 2008. 


\section{Figure}

Figure 1: Map of the Bay of Biscay ${ }^{9}$

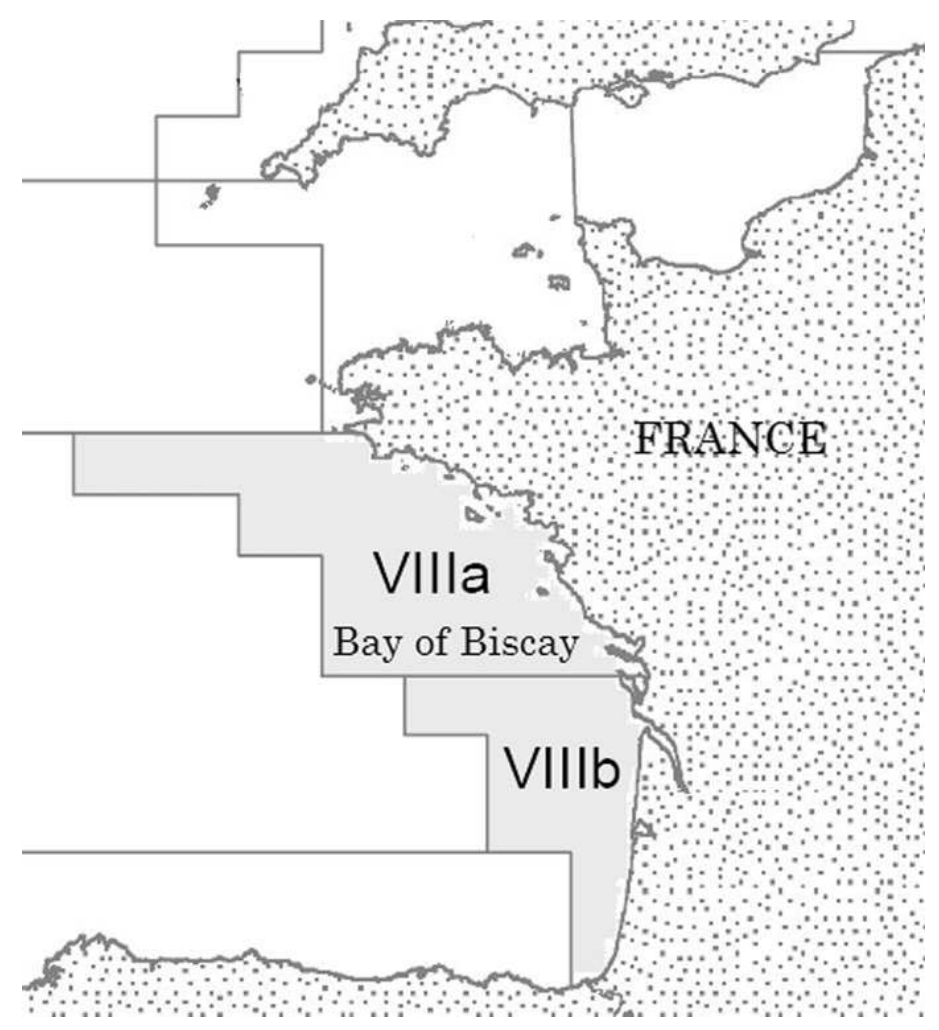

Figure 2a: Nephrops landings at MSY (single species simulation)

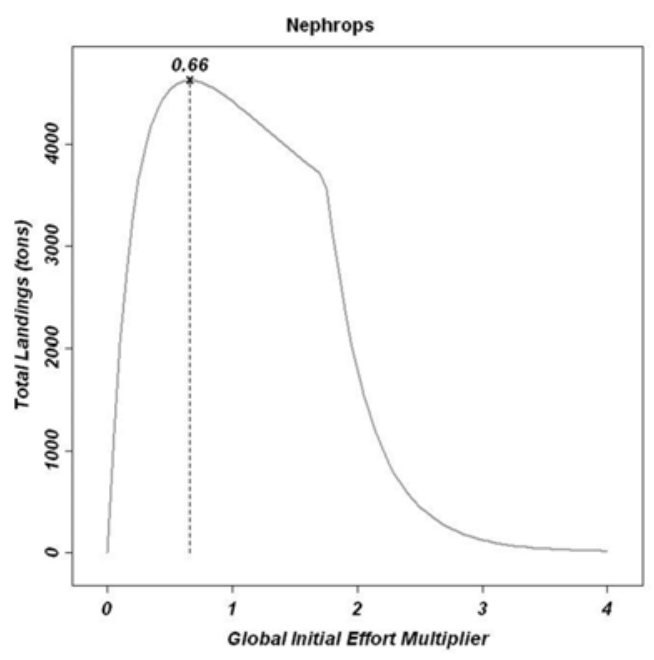

\footnotetext{
${ }^{9}$ The Bay of Biscay lies along the western coast of France, from Brest south to the Spanish border, and the northern coast of Spain west to Cape Ortegal in A Coruña.
} 
Figure 2b: Hake landings at MSY (single species simulation)

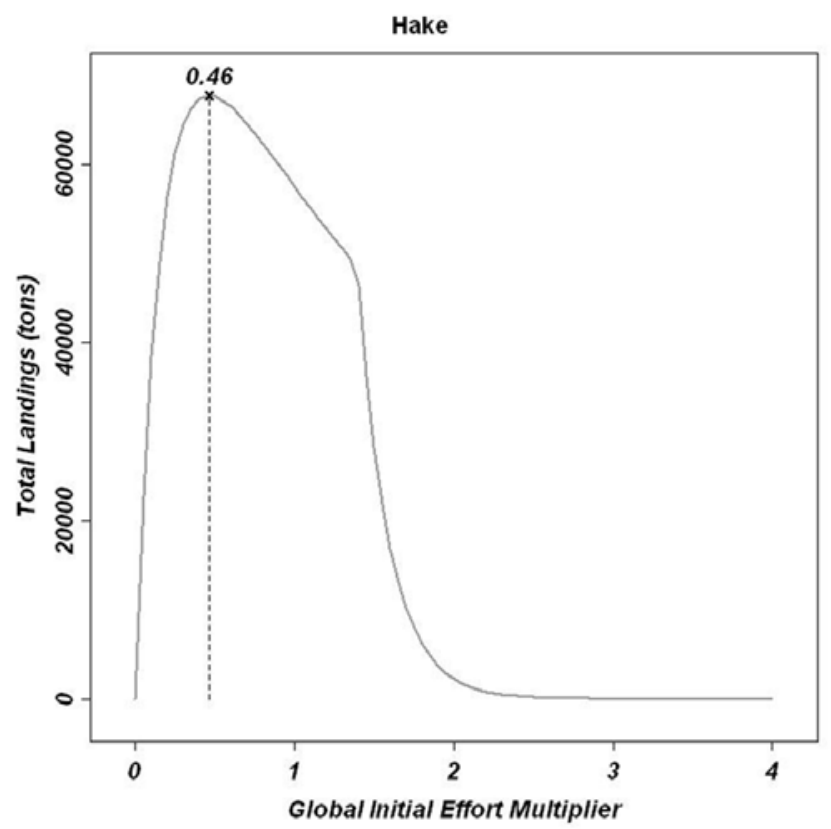

Figure 2c: Sole landings at MSY (single species simulation)

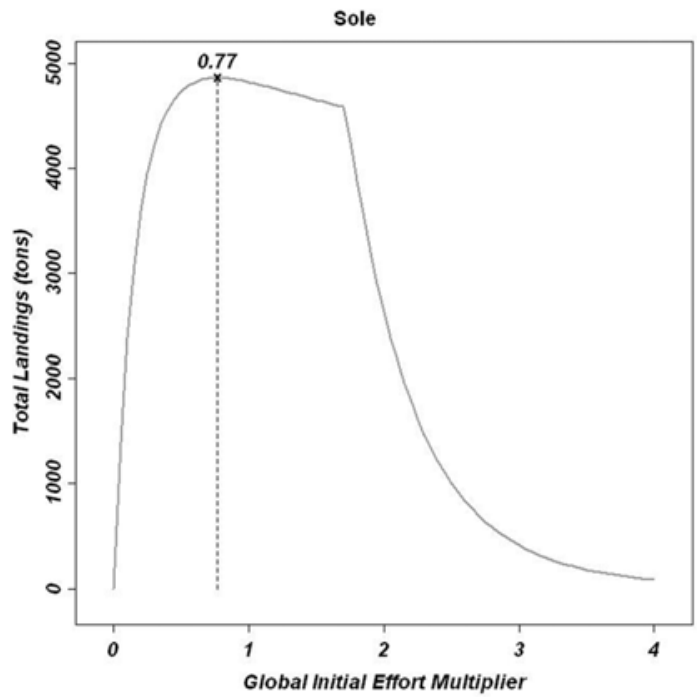


Figure 3: Landings at MSY considering the multi-species characteristics of the fishery

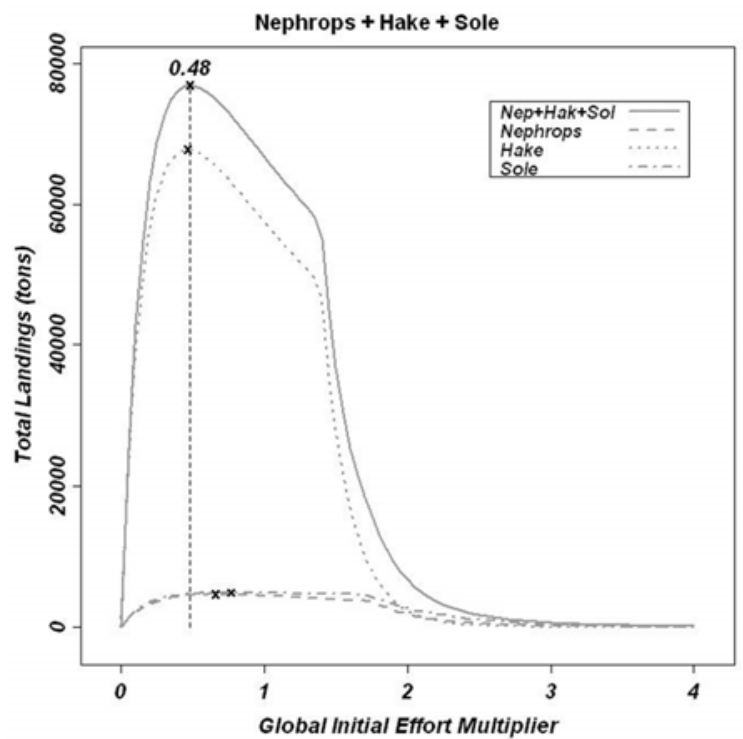

Figure 4a: Nephrops landings at MSY (single species simulation) with optimal effort allocation by fleet

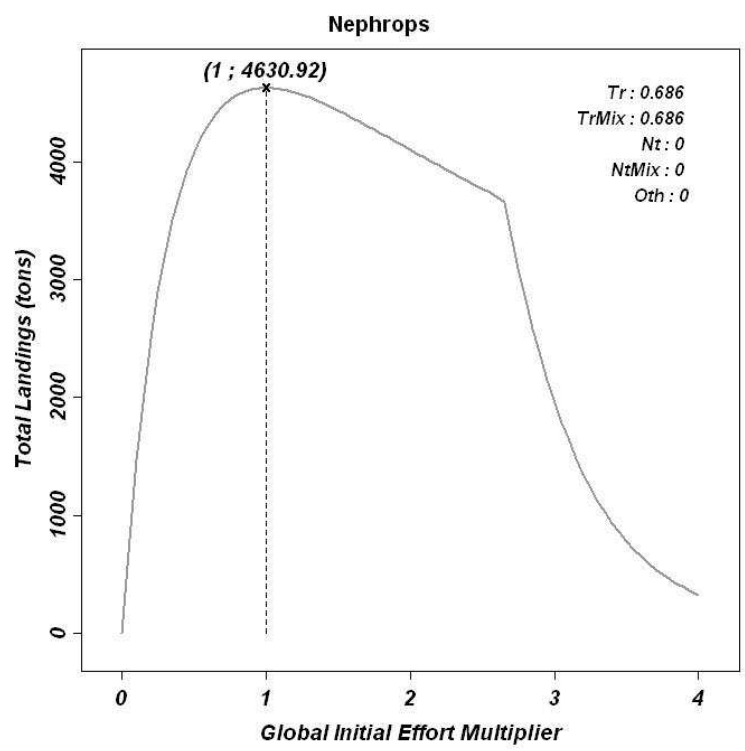


Figure 4b: Hake landings at MSY (single species simulation) with optimal effort allocation by fleet

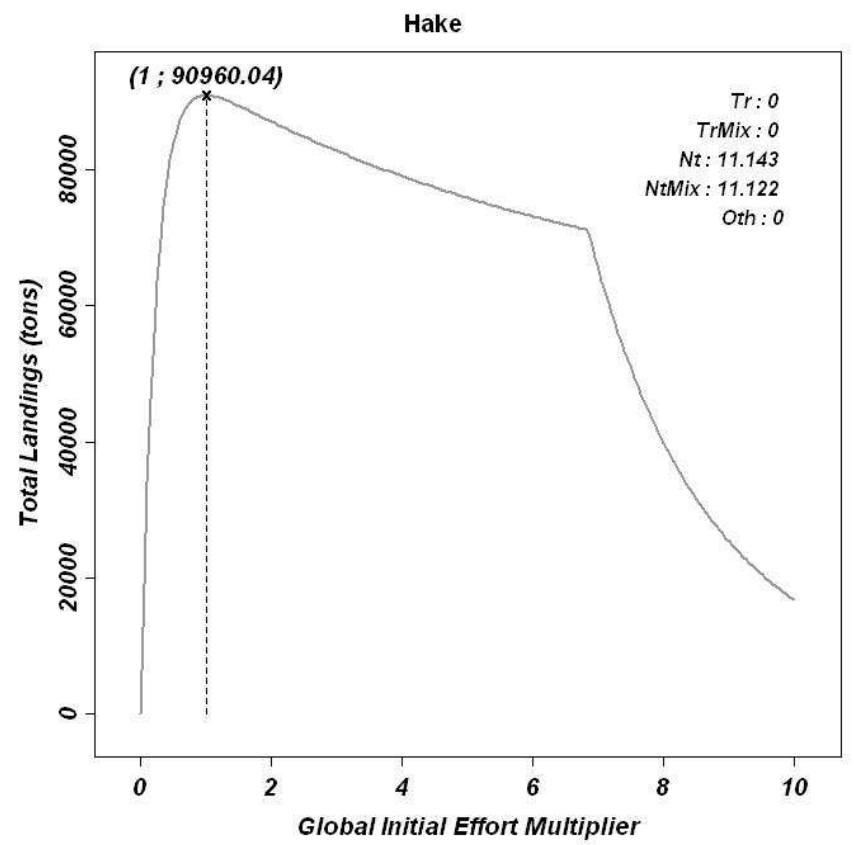

Figure 4c: Sole landings at MSY (single species simulation) with optimal effort allocation by fleet

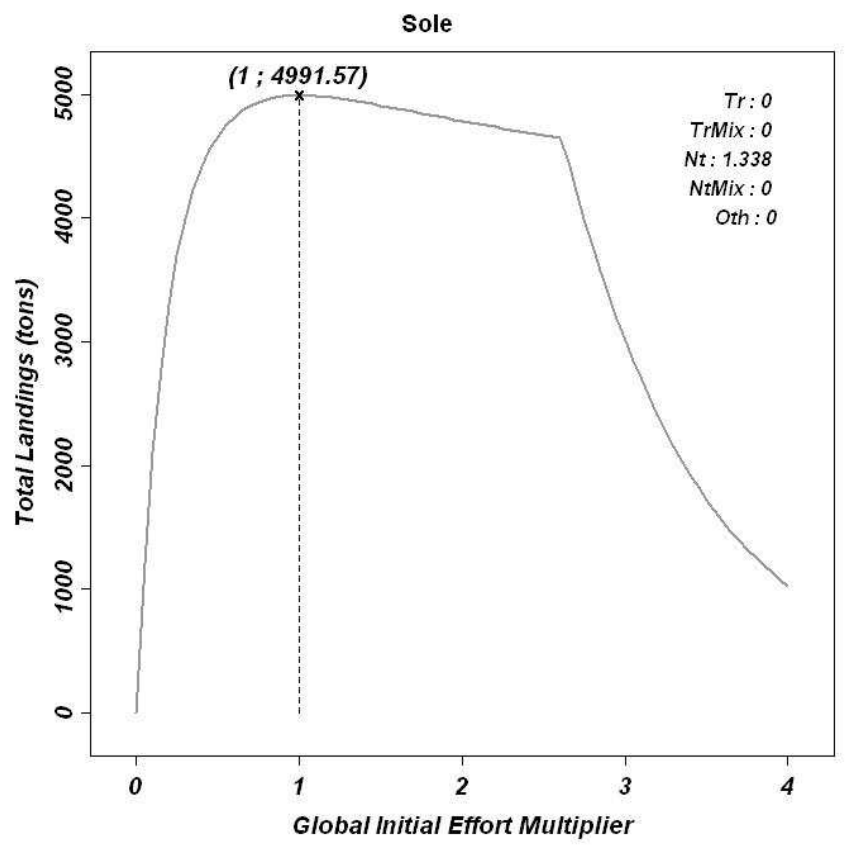


Figure 4d: Maximum total landings at MSY with optimal effort allocation by fleet

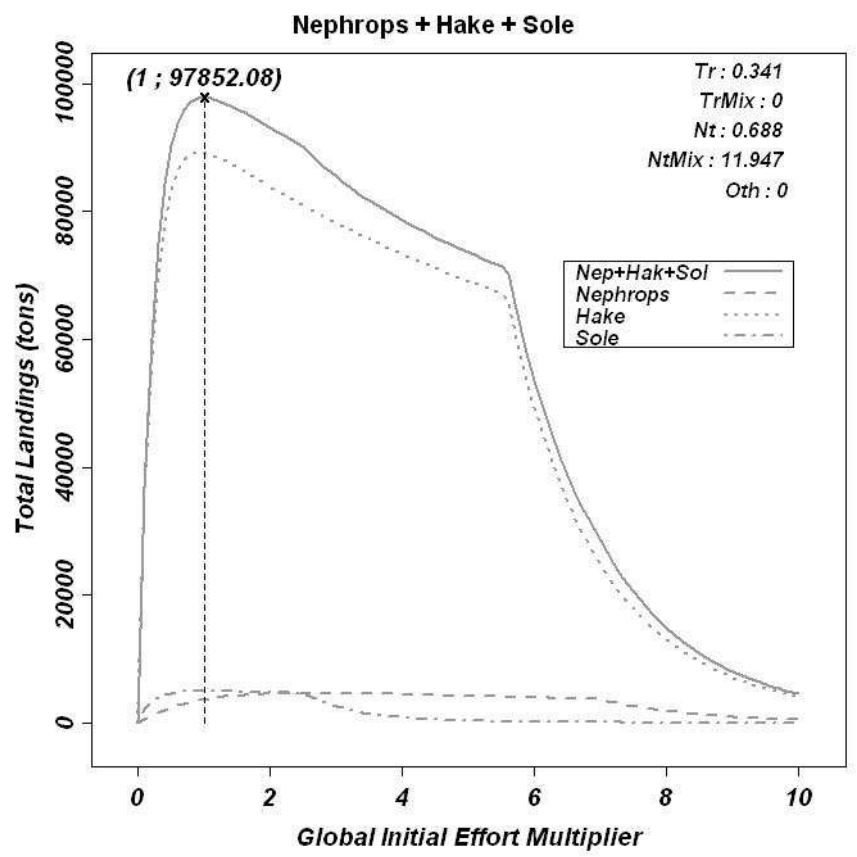

Figure 5a: MEY with proportional effort allocation by fleet considering other species constant

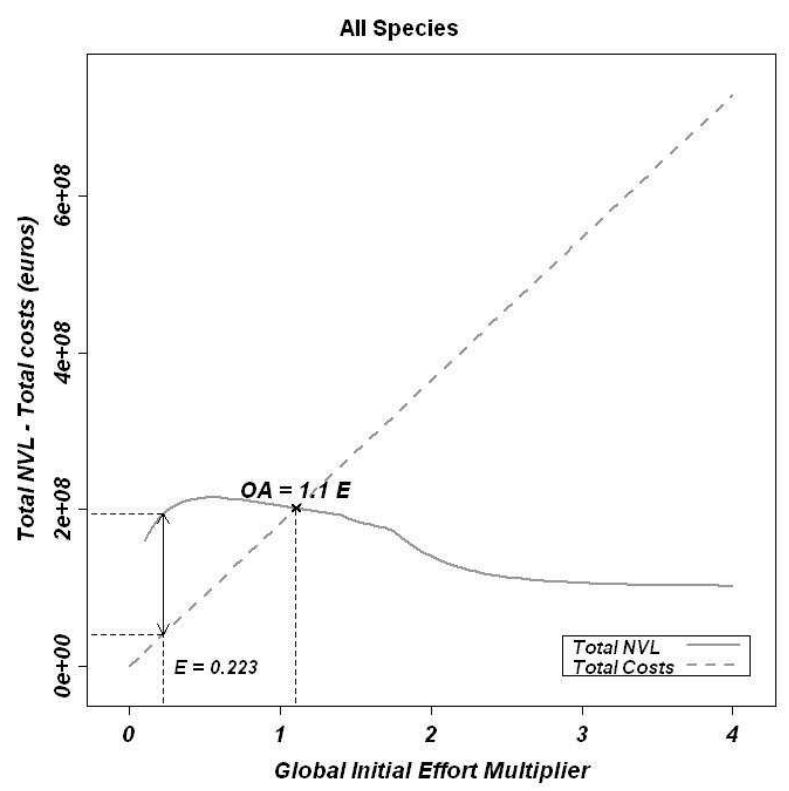


Figure 5b: MEY with proportional effort allocation by fleet considering other species proportional

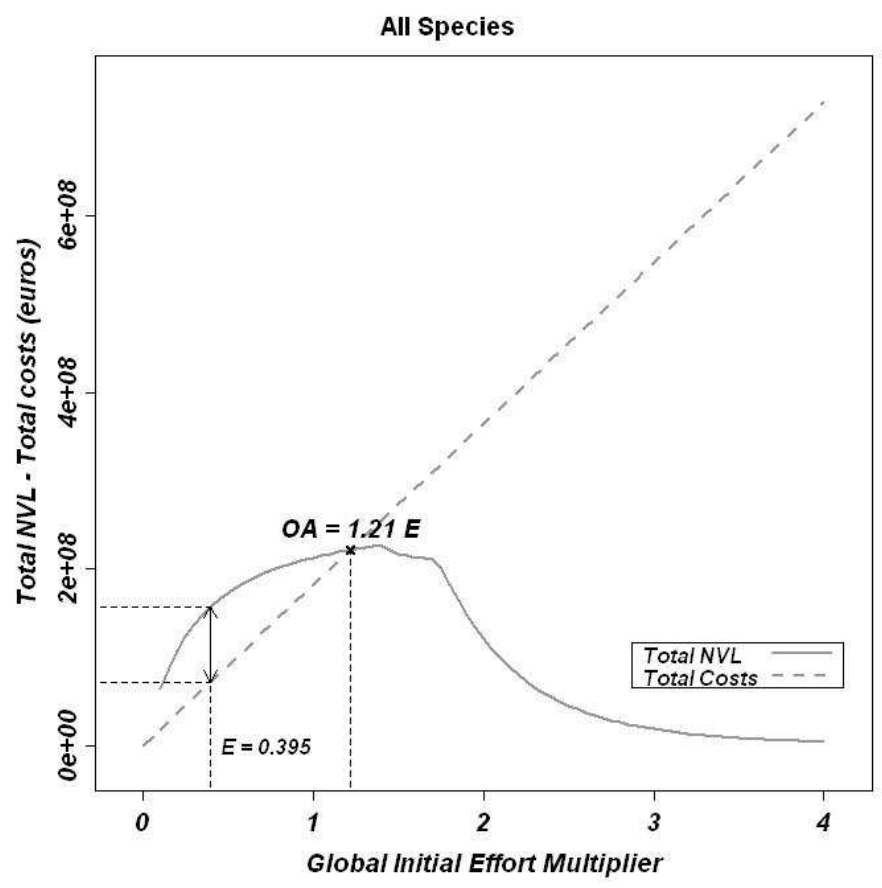

Figure 6a: MEY with optimal effort allocation by fleet considering other species constant

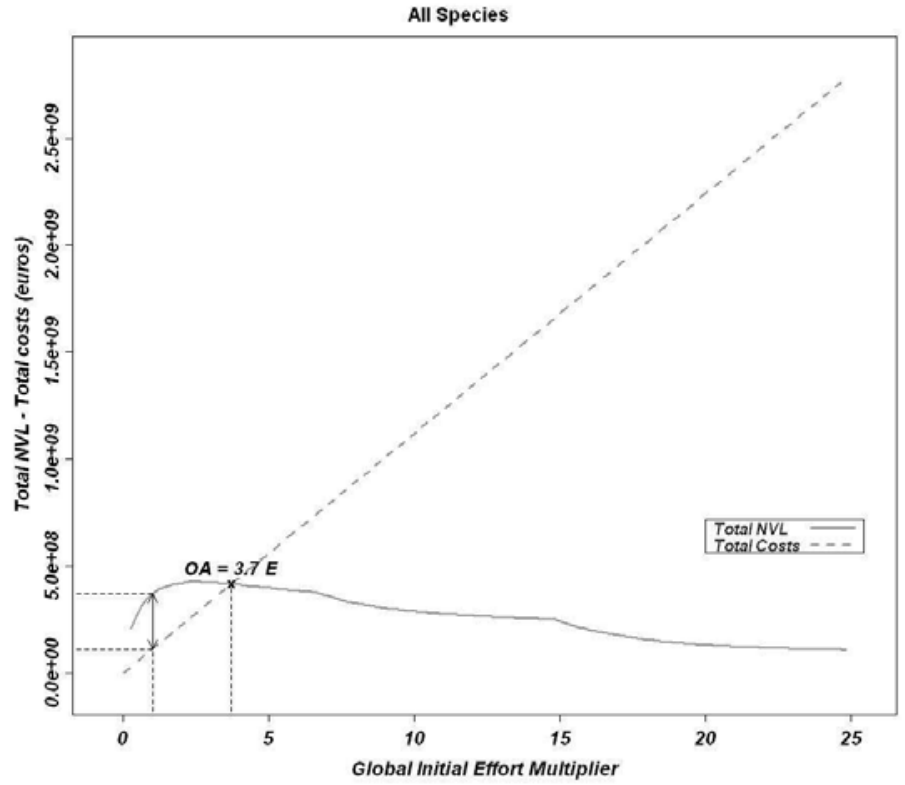


Figure 6b: MEY with optimal effort allocation by fleet considering other species proportional

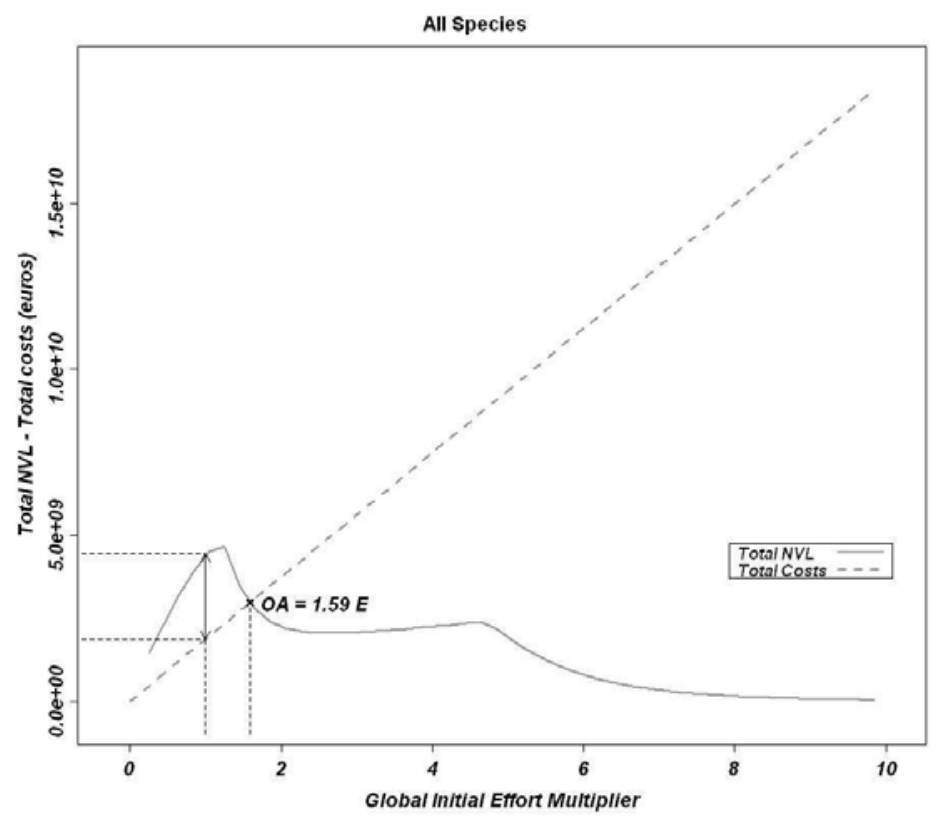


Table 1: Main data for the fleets involved in the demersal mixed fishery (2009)

\begin{tabular}{|c|c|c|c|c|c|c|}
\hline Variables/Fleets & $\begin{array}{l}\text { Trawler } \\
\text { Nephrops }\end{array}$ & \begin{tabular}{|l|} 
Trawler \\
Mix \\
\end{tabular} & $\begin{array}{l}\text { Gillnetter } \\
\text { Mix }\end{array}$ & \begin{tabular}{|l|}
$\begin{array}{l}\text { Gillnetter } \\
\text { Sole }\end{array}$ \\
\end{tabular} & \begin{tabular}{|l|} 
Other \\
Fleets \\
\end{tabular} & TOTAL \\
\hline Number of Vessels & 116 & 241 & 86 & 105 & NA & NA \\
\hline F nephrops & 0.32 & 0.10 & 0.00 & 0.00 & 0.02 & 0.43 \\
\hline F hake & 0.01 & 0.02 & 0.04 & 0.00 & 0.49 & 0.57 \\
\hline F sole & 0.02 & 0.05 & 0.01 & 0.21 & 0.06 & 0.35 \\
\hline Q nephrops (Tons) & 4,642 & 1,437 & 0 & 0 & 279 & 6,358 \\
\hline Q hake (Tons) & 866 & 1,819 & 4,320 & 344 & 48,943 & 56,291 \\
\hline Q sole (Tons) & 253 & 845 & 123 & 2,273 & 717 & 4,210 \\
\hline D nephrops (Tons) & 1,650 & 511 & 0 & 0 & 99 & 2,259 \\
\hline D hake (Tons) & 403 & 452 & 0 & 0 & 2,520 & 3,374 \\
\hline D sole (Tons) & 0 & 0 & 0 & 0 & 0 & 0 \\
\hline L nephrops (Tons) & 2,993 & 926 & 0 & 0 & 180 & 4,099 \\
\hline L hake (Tons) & 463 & 1,367 & 4,320 & 344 & 46,423 & 52,917 \\
\hline L sole (Tons) & 253 & 845 & 123 & 2,273 & 717 & 4,210 \\
\hline L Total (Tons) & 6,817 & 22,054 & 8,468 & 5,926 & $\mathrm{NA}$ & 43,265 \\
\hline V nephrops (000 Euros) & 29.4 & 9.1 & 0.0 & 0.0 & NA & $38.5^{*}$ \\
\hline V hake (million Euros) & 1.0 & 3.2 & 11.4 & 0.9 & NA & $16.5^{*}$ \\
\hline V sole (million Euros) & 2.7 & 9.1 & 1.5 & 27.8 & NA & $41.2 *$ \\
\hline Total Landings Value (million Euros) & 37.1 & 85.0 & 37.2 & 45.0 & NA & $204.3^{*}$ \\
\hline Total Costs (million Euros) & 33.7 & 79.6 & 29.5 & 37.5 & NA & $180.4^{*}$ \\
\hline Gross Value Added (million Euros) & 18.5 & 37.2 & 23.8 & 27.0 & $\mathrm{NA}$ & $106.5^{*}$ \\
\hline Gross cash Flow (million Euros) & 3.4 & 5.4 & 7.6 & 7.5 & NA & $23.9 *$ \\
\hline
\end{tabular}

*Excluding the other fleet. 
Table 2: Summary results from the MSY estimations

\begin{tabular}{lrrrrrrrr} 
& \multicolumn{3}{c}{ Single-species simulations } & & \multicolumn{3}{c}{ Multi-species simulation } \\
\cline { 2 - 4 } \cline { 7 - 9 } & Nephrops & Hake & \multicolumn{2}{c}{ Sole } & & Nephrops & Hake & \multicolumn{2}{c}{ Sole } \\
\cline { 2 - 4 } Effort (E) & 0.66 & 0.46 & 0.77 & & 0.48 & 0.48 & 0.48 \\
\hline Catches (Tons) & 6,308 & 69,500 & 4,860 & & 5,846 & 69,533 & 4,706 \\
\hline Landings (Tons) & 4,631 & 67,728 & 4,860 & & 4,514 & 67,701 & 4,706 \\
\hline Discards (Tons) & 1,677 & 1,772 & 0 & & 1,332 & 1,832 & 0 \\
\hline Biomass (Tons) & 28,393 & 309,333 & 24,418 & & 34,855 & 300,962 & 34,376 \\
\hline
\end{tabular}


Table 3: Results from the MSY estimations with optimal effort allocation by fleet

\begin{tabular}{lrrrrrrrr} 
& \multicolumn{3}{c}{ Single-species simulations } & & \multicolumn{3}{c}{ Multi-species simulation } \\
\cline { 2 - 4 } \cline { 7 - 9 } & Nephrops & Hake & \multicolumn{2}{c}{ Sole } & & Nephrops & Hake & \multicolumn{2}{c}{ Sole } \\
\cline { 2 - 4 } Effort Trawler Nephrops & $0.69^{10}$ & 0 & 0 & & 0.34 & 0.34 & 0.34 \\
\hline Effort Trawler Mix & 0.69 & 0 & 0 & & 0 & 0 & 0 \\
\hline Effort Gillnetter Sole & 0 & 11.14 & 1.34 & & 0.69 & 0.69 & 0.69 \\
\hline Effort Gillnetter Mix & 0 & 11.12 & 0 & & 11.95 & 11.95 & 11.95 \\
\hline Effort Other Fleets & 0 & 0 & 0 & & 0 & 0 & 0 \\
\hline Catches (Tons) & 6,308 & 90,960 & 4,992 & & 4,430 & 89,394 & 4,973 \\
\hline Landings (Tons) & 4,631 & 90,960 & 4,992 & & 3,648 & 89,232 & 4,973 \\
\hline Discards (Tons) & 1,677 & 0 & 0 & & 782 & 162 & 0 \\
\hline Biomass (Tons) & 28,392 & 260,170 & 25,286 & & 49,132 & 255,192 & 24,862 \\
\hline
\end{tabular}

\footnotetext{
${ }^{10}$ In this case, because trawlers have the same selectivity whether they focus more fishing days or less targeting nephrops, the maximum landings of nephrops can be obtained by different combination of effort for both fleets. These combinations go from an effort multiplier of 0.9 for trawlers targeting nephrops and 0 for trawlers mix to 0 for trawlers targeting nephrops and 2.9 for trawlers mix, passing through the point where both efforts are 0.69 .
} 
Table 4: Results from the MEY estimations

\begin{tabular}{|c|c|c|c|c|c|c|}
\hline \multirow[b]{3}{*}{ 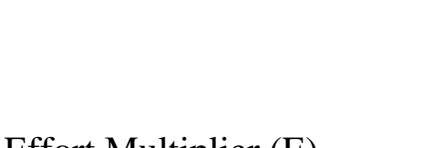 } & \multicolumn{3}{|c|}{ Other species constant } & \multicolumn{3}{|c|}{ Other species proportional } \\
\hline & Nephrops & Hake & Sole & Nephrops & Hake & Sole \\
\hline & 0.22 & 0.22 & 0.22 & 0.39 & 0.39 & 0.39 \\
\hline Catches (Tons) & 4,162 & 59,752 & 3,769 & 5,471 & 68,808 & 4,542 \\
\hline Landings (Tons) & 3,451 & 58,844 & 3,769 & 4,328 & 67,268 & 4,542 \\
\hline Discards (Tons) & 711 & 908 & 0 & 1143 & 1,539 & 0 \\
\hline Biomass (Tons) & 51,429 & 479,306 & 53,977 & 39,147 & 344,908 & 39,154 \\
\hline NHS Revenues ('000 EUR) & & 93,265 & & & 110,991 & \\
\hline Total Revenues ('000 EUR) & & 194,675 & & & 157,460 & \\
\hline Total Costs ('000 EUR) & & 40,675 & & & 72,101 & \\
\hline Total Profits ('000 EUR) & & 154,000 & & & 85,359 & \\
\hline
\end{tabular}


Table 5: Results from the MEY estimations with optimal Effort allocation by fleet

\begin{tabular}{|c|c|c|c|c|c|c|}
\hline \multirow[b]{3}{*}{ Effort Multiplier Trawlers Nephrops } & \multicolumn{3}{|c|}{ Other species constant } & \multicolumn{3}{|c|}{ Other species proportional } \\
\hline & Nephrops & Hake & Sole & Nephrops & Hake & Sole \\
\hline & 0.36 & 0.36 & 0.36 & 0.50 & 0.50 & 0.50 \\
\hline Effort Multiplier Mixed Trawlers & 0 & 0 & 0 & 0 & 0 & 0 \\
\hline Effort Multiplier Gillnetters Sole & 0.29 & 0.29 & 0.29 & 0 & 0 & 0 \\
\hline Effort Multiplier Mixed Gillnetters & 2.97 & 2.97 & 2.97 & 62.31 & 62.31 & 62.31 \\
\hline Effort Multiplier Other Fleets & 0 & 0 & 0 & 0 & 0 & 0 \\
\hline Catches (Tons) & 4,582 & 62,590 & 4,227 & 5,327 & 73,508 & 4,637 \\
\hline Landings (Tons) & 3,756 & 62,416 & 4,227 & 4,245 & 73,274 & 4,637 \\
\hline Discards (Tons) & 826 & 173 & 0 & 1,082 & 233 & 0 \\
\hline Biomass (Tons) & 47,789 & 499,319 & 47,833 & 40,664 & 147,579 & 13,202 \\
\hline NHS Revenues ('000 EUR) & & 267,082 & & & 277,869 & \\
\hline Total Revenues ('000 EUR) & & 368,492 & & & $4,458,931$ & \\
\hline Total Costs ('000 EUR) & & 112,011 & & & $1,873,212$ & \\
\hline Total Profits ('000 EUR) & & 256,481 & & & $2,585,719$ & \\
\hline
\end{tabular}

